\title{
U.S. Regional Scorecard: Comparing U.S. Regions for Selected Economic Variables
}

\author{
Joseph Ejike 0jih \\ Earl G. Graves School of Business and Management, Morgan State University, Baltimore, Maryland \\ Email: Joseph.ojih@morgan.edu
}

How to cite this paper: Ojih, J. E. (2021). U.S. Regional Scorecard: Comparing U.S. Regions for Selected Economic Variables. Open Journal of Business and Management, 9, 1089-1103.

https://doi.org/10.4236/ojbm.2021.93058

Received: February 10, 2021

Accepted: May 10, 2021

Published: May 13, 2021

Copyright (อ 2021 by author(s) and Scientific Research Publishing Inc. This work is licensed under the Creative Commons Attribution International License (CC BY 4.0).

http://creativecommons.org/licenses/by/4.0/ (c) (i) Open Access

\begin{abstract}
In this paper, the patterns of differences of some key economic variables among the four major U.S. regions are investigated. These four regions include: Northeast, Midwest, South and West. The grouping of individual U.S. states into these four regions is in accordance with the U.S. Census Bureau and the U.S. Department of Commerce classification. Two main points are explored in this study. The first one examined and summarized the descriptive statistics of the variables for states in these four regions. These variables and data were culled from the databases of U.S. Census Bureau, the Bureau of Economic Analysis (BEA), the U.S. Department of Commerce, the Bureau of Labor Statistics, World Population Review and the U.S Department of Agriculture. The second one covered the identification of the four regions' similarities and dissimilarities for the identified variables. One-way analysis of variance (ANOVA) is the statistical tool for the testing hypothesis of four regions' means equality. To ascertain whether the regions that ranked the highest actually differ from another and from the remaining regions, the researcher made use of multiple comparison procedures, specifically the Scheffe test.
\end{abstract}

\section{Keywords}

Economic Variables, Inflation, Warning Signals, Scheffe Test, U.S.

\section{Introduction}

In November of 2018, Forbes magazine published a report in which it claimed that the U.S. State of California would be the fifth biggest economy in the world if it were a country. The report noted that with an economy that is worth approximately $\$ 2.9$ trillion, California is ranked between Germany and the United Kingdom with respect to the size of the economy (Forbes Media, 2018). In one 
of his articles on the richest and poorest states in America, Suneson (2018) draw on four categories of data (median household income, population, unemployment rate, and poverty rate) to support his argument that many of the wealthiest states in the country are coastal states in the West, Mid-Atlantic, and Northeast regions. In a similar report published by the U.S News and World Report, it was noted that the states of the east coast and west coast (particularly California, Oregon, New York, Washington, Florida, Massachusetts, Connecticut, and Maryland, among others) were among the states ranked the best states in America in terms of the business environment, employment and growth (U.S. News \& World Report, 2019). This study will seek to answer these questions, among others: on what data are these publications basing these claims? How accurate are these bold claims? In plain terms, to make any form of inference about the economy of a state or a country, researchers generally make use of the available published economic and financial statistics or indicators.

Elsewhere, the past few years have seen several researchers and policymakers in total agreement that economic and financial statistics reveal a thorough picture of the economy of the affected states or nations (Zhuang \& Dowling, 2003; Kaminsky, 1999; Babecky et al., 2013). One way they did this is by showing that the information contained in economic and financial data can serve as warning signals about the economy of any state, region or country. Zhuang and Dowling's (2003) interest in this area covers the lessons of the Asian financial crises as they relate to what early signals comprising of economic and financial statistics can tell us about the state of an economy. They noted that these warning signals that pointed to fundamental weaknesses included data showing the real appreciation of domestic currencies, bust of asset price bubbles, economic slowdown, deterioration in current account positions, excessive external borrowings by banks and currency mismatches in their balance sheets, and excessive growth of domestic credit. According to them, these warning signals actually revealed heightened economic and financial vulnerabilities in the affected Asian countries prior to the crises.

Kaminsky (1999) provides insight on how effective economic and financial statistics, which she termed early warnings of distress, can be in estimating crises-triggering threshold values and defining the direction of an economy. Her work in this area covered 102 financial crises in 20 countries and she attempted to use the findings to explain the Asian crisis of 1997. In her view, a lot of researchers claimed that the 1997 Asian crises, due to its abruptness and virulence, are of a new breed and were hence unforecastable. She argued that economic and financial crises, including the 1997 Asian crises, are not of a new variety. According to her, such crises occur when economies are in distress and this makes the degree of fragility of the economy as indicated by the economy's economic and financial statistics a useful metric for predicting future crises. In line with this idea, she put forward different composite leading indicators of crises and also evaluated their accuracy of both the out-of-sample and in-sample. 
Babecky et al. (2013) offer an explanation consistent with the argument that the recent financial crisis reignited interest in the early warning literature among both researchers and policy-makers. In their view, the literature dates back to the 1970s, the era in which several currency crises generated interests in the economic and financial statistics that serve as the leading indicators as well as on the theoretical models explaining such crises. They noted that it was only in the first golden era of the early warning literature, in the 1990s, that a wide-ranging methodological debate (including studies on, say, banking, the balance of payment problems and currency crashes) started. According to them, this methodological debate also served as a starting point for the current stream of literature motivated mainly by the financial crises that occurred during the past decade. Their work in this area supports their emphatic stand that the economic and financial statistics, which serve as the early warning signals, also offer many useful lessons on how to approach the new generation of the early warning models.

Academic research by Kaminsky and Reinhart (1999), Cecchetti et al. (2010) and Babecky et al. (2013) found that various financial indicators might carry useful information regarding future costly events. These financial indicators, according to these researchers, include liquidity and leverage ratios, the ratio of regulatory capital to risk-weighted assets, the deposit-loan ratio for households, and credit to households. They also noted that the data series required for computing these indicators are only available for some countries and limited time periods.

More research finds evidence that not all economic and financial variables qualify as leading or early warning indicators. Kaminsky (1999) reason that studies using the discrete representation of the dependent variable and the signaling approach, for instance, usually evaluate each indicator separately by minimizing either the signal-to-noise ratio or the loss function(as cited in Babecky et al., 2013). Other researchers, particularly Borio \& Lowe (2002), combined potential economic and financial indicators into composite indices using judgmental approaches to select the index components and computing thresholds for the corresponding variables simultaneously. Their reason for adopting this approach is clear: even when policymakers use several early warning models in parallel, they still face the risk of underestimating the probability of a crisis if more economic and financial indicators are close to, albeit below, their individual threshold values.

In the light of the above explanations, it becomes necessary to establish that the information revealed by economic and financial statistics makes good sense. The bottom line is that if such economic and financial statistics do reveal the true state of an economy then appropriate policy and institutional reforms should be implemented whenever they reveal the fundamental weakness in the economy of a state or a nation.

The purpose of this paper is to use economic and financial statistics from five government agencies and from a private data firm to identify and analyze similarities as well as the dissimilarities between the four U.S regions (namely, the 
northeast, Midwest, south, and west). The economic and financial statistics on the states in these regions, which were published by the aforesaid government agencies and the private data firm forms the basis of this comparison. The agencies in that regard include U.S. Census Bureau, the Bureau of Economic Analysis (BEA), the U.S. Department of Commerce, the U.S Department of Agriculture, and the Bureau of Labor Statistics. The private data firm is the World Population Review, which has a database that contained and as well as ranked cost of living by factoring in the cost of grocery, housing, utility, and transportation at all U.S. states and the District of Columbia (World Population Review, 2020). The analysis and comparisons will cover not just the regions' gross domestic products (GDP), but also other economic and financial variables, including employment, consumer spending, personal income, and so on. In all, the data are for 9 variables at the state level, which will be aggregated the four regional level, the U.S. northeast, Midwest, south and west. It should be noted that the choice of using data from these agencies and from the World Population Review is prompted by the fact that they are rich sources of reliable economic and financial statistics (or variables) about the states in the U.S. four regions. A full discussion of the economic and financial variables will be presented in the data and method section. What follows are the literature review, the data and method, the results, and the conclusions.

\section{Literature Review}

The use of economic and financial variables or statistics to describe the economic performance of states or countries is nothing new. In fact Thomas Robert Malthus (1766-1834), an English economist, popularized this practice as far back as 1826 when he wrote his "Essay on the Principle of Population" (as cited in Ball, 2004). This essay, which is a compelling critique of unchecked population growth, had a profound influence on both the governments of Europe and the United States: it prompted them to begin to appreciate not only the wisdom of counting citizens but also the importance of using some type of social numbers to provide insights in how their societies functions (Ball, 2004).

Other related studies on the use of economic and financial variables to describe the state of the economy of a country or a state abound: a study by Babecky et al. (2013) showed that economic and financial variables (or statistics) used as early warning indicators may be useful in identifying the onset of a crisis in real time. They noted that such statistics may be used to compile a database of crises occurrence ex-post - a database that has the benefit of hindsight, especially given that it would not be available to policy makers when examining or accessing risks to macroeconomic stability in real time. According to them, even those economic and financial variables that serves as late warning indicators bordering with the symptoms of crises could, to a very large extent, be viewed as signals containing useful early warning information.

Garner's (1995) work in this area covered the usefulness of economic and fi- 
nancial variables (or statistics) in predicting inflation. He showed that economic and financial variables (or statistics) serving as leading inflation indicators are useful primarily as potent tools for signaling or confirming an inflation turning point. He noted that among the set of leading indicators, composite indexes are very powerful in terms of providing the most reliable signals of turning points. He further explained that other economic models and statistics can equally go a long way toward providing more accurate forecasts of future inflation magnitudes.

Zhuang and Dowling (2003) work added a strong impetus to the assessment of economic and financial variables (or statistics) vis-a-vis the state of an economy by showing how accurate they are in predicting the causes of the 1997 Asian financial crises. Through their work, they examined 38 economic and financial variables (or statistics) which they gave the name warning signals. They observed that during the 24 months prior to the 1997 Asian financial crises, these warning signals pointed to the four sources of fundamental weaknesses in each of the affected countries at the time. First, they revealed that there were appreciations in the real exchange rate against both the US dollar and the basket currencies of the major trading partners in most of the countries they examined. Their work showed that this real appreciation is the contributing factor that caused the deteriorations in the affected countries' trade and current account positions. Second, the persistent warning signals indicated that there were apparent problems in the affected countries' capital accounts: for instance, in Indonesia, this fact was revealed by the ratio of M2 (a broader definition of money supply) to foreign reserve; and in Malaysia, Thailand and Indonesia by the ratio of foreign liabilities to foreign assets of their individual banking sectors. Third, they also revealed strong evidence of excessive growth of domestic credits in the affected countries, particularly in Thailand, Philippines, Malaysia and Korea. Finally they found that, especially in Korea and Thailand, these warning signals showed compelling evidence of deteriorations in the real sector of the countries.

Edison's (2003) study was an attempt to develop an operational early warning system (EWS) that can detect financial crises, a system that would comprise of various forms of economic and financial variables (or statistics). His work in this area was founded on the signal approach model developed by Kaminsky et al. (1998), a type of early warning system that monitors several economic and financial indicators that generally exhibit an unusual behavior in periods preceeding a crisis. According to Edison, though the model developed by these researchers does have some weaknesses, it did a good job of anticipating some of the crises that occurred in 1997/1998, because of its ability to consistently show the symptoms of impending financial crises. Overall, Edison presented a persuasive evidence that an early warning system in form of a model whose components are differrent forms of economic and financial indicators should be thought of as a useful diagnostic tool.

Hubbard \& O'Brien (2009) reported that economic and financial statistics provide measurements for evaluating the health of a state or an economy, the 
latest business cycle, as well as how consumers are spending and generally faring. Because such economic and financial statistics, according to them, are generally tracked in order to evaluate the economy in different ways or from different perspectives, they are often released daily, weekly, monthly, and quarterly. They noted that it is hence not surprising why governments, businesses, and investors use these economic and fiancial statistics as measures of how well an economy or a state is meeting its goals: they help governments, researchers, policy makers, businesses and investors to keep a pulse on the economy.

Literature review revealed that economic and financial statistics can give researchers, businesses, policy makers, investors and government, among others, a sense of where the economy is headed in the future. The next sections tackle data and method, followed by the results and conclusion methods.

\section{Data and Method}

As pointed out earlier in the study, the data were obtained from U.S. Census Bureau, the U.S. Department of Commerce, the Bureau of Economic Analysis (BEA) and the Bureau of Labor Statistics. These government agencies provided a rich source of 7 current economic and financial statistics for a period covering 2017 to 2018. The only data that came from a different source are the cost of living and the percentage of the participants in each region's Supplemental Nutrition Assistance Program (SNAP, formerly called food stamps). The cost of living data was obtained from the World Population Review database, a database that contained and ranked cost of living by factoring in the cost of grocery, housing, utility and transportation at all U.S. states and the District of Columbia. The number of participants in the SNAP data was obtained from the U.S Department of Agriculture database. The following variables, which were denoted by $\mathrm{X}_{1}, \mathrm{X}_{2}$, $\mathrm{X}_{3}, \ldots, \mathrm{X}_{9}$, are used to summarize the three region's economic and financial variables in accordance with these government and nonprofit agencies' definitions, as follows:

$\mathrm{X}_{1}=$ Gross domestic product (GDP)

$\mathrm{X}_{2}=$ Personal income $(\mathrm{PI})$

$\mathrm{X}_{3}=$ Personal consumption expenditures (PCE)

$\mathrm{X}_{4}=$ Participants in SNAP program

$\mathrm{X}_{5}=$ New residential sales

$\mathrm{X}_{6}=$ Unemployment rate

$\mathrm{X}_{7}=$ Nonfarm payroll employment

$\mathrm{X}_{8}=$ Population of minimum wage workers (PMW)

$\mathrm{X}_{9}=$ Cost of living (measured by the World Population Review cost of living index)

To test the hypothesis that the regional means of the variables are equal, a statistical method called one-way analysis of variance (one-way ANOVA) was used. This method was used because of one of its important features: it makes it possible to ascertain whether the regions differ from each other for the variables when 
the total variances are decomposed. For this one-way ANOVA, the null $\left(\mathrm{H}_{0}\right)$ and alternative $\left(\mathrm{H}_{1}\right)$ hypotheses were stated thus:

$\mathrm{H}_{0}: \mu_{1}=\mu_{2}=\mu_{3}=\mu_{4}$.

$\mathrm{H}_{1}$ : At least two $\mu$ 's are different.

where $\mu i$ are the means of the 9 variables under study. It is important to note here that there are 9 of such hypothesis in this study, with each of them used to test the equality of means between the four U.S. regions: Northeast, Midwest, South and West.

The decision criteria for one-way ANOVA as used in this study are this: if $\mathrm{H}_{0}$ is rejected, then the inequality of the means is caused by a collection of regions with equivalent means differing from another collection of regions with equivalent means. Given that F-ratios for equality of regional means cannot be used for accepting any particular alternative hypothesis, the researcher explored the nature of differences by choosing the multiple comparison method: a method involving the ranking of the means while, at the same time, noting whether the means ranked highest really differed from one another and from the remaining means. The decision rule for each hypothesis (for an $\alpha$-level test) is clear: reject the null hypothesis (that is, the $\mathrm{H}_{0}$ ) if

$$
F=\frac{M S R}{M S E}>F(\alpha, k-1, n-k),
$$

where $M S E$ and $M S R$ are the error means square and the mean square for the regions respectively. The values $k-1$ and $n-k$ represents the degrees of freedom (henceforth, the $d f$ ) and are used to determine the critical values of the F-test at the $a$ level of significance. For this study, $k=4$ (for the number of regions) and $n=9$ (number of observations). The summary of the computations was presented in Tables 1-6, and the results are discussed in the following sections of this study.

\section{Results}

The summary descriptive statistics of the 9 variables solicited from the U.S. Census Bureau, the U.S. Department of Commerce, the Bureau of Economic Analysis (BEA), the Bureau of Labor Statistics, U.S Department of Agriculture, and the World Population Review are presented in Table 1. The table also contained the mean, the standard deviation, the minimum and maximum of these variables for the four regional classifications as well as for the United States as a whole. It is worth noting that the summaries presented in Table 1 are based on 50 states' and Washington District of Columbia data.

For the United States, the average gross domestic product (GDP) in 2018 is $\$ 401,244.3$ million with a standard deviation of $\$ 522,698.2$ million, a minimum $\$ 33,256.3$ million and a maximum $\$ 2,997,733$ million, indicating a wide spread. The personal income mean is $\$ 17,813,035$ million with a standard deviation of $\$ 235,888.14$ million, a minimum of $\$ 17,535,505$ million and a maximum of $\$ 18,077,710$ million. 
The mean personal consumption expenditures for the United States is $\$ 284,015$ million with a standard deviation of $\$ 336,503.7$ million, a minimum of $\$ 24,707$ million and a maximum of $\$ 1,858,421$ million. The participants in the SNAP program ranged from a minimum 38,853 participants to a maximum $4,340,042$ participants, with an average of $865,475.90$ participants and a standard deviation of $952,649.60$. These values indicate a wide spread, which implies that while some of the states and regions attracted a very large number of participants in 2018, others had very small amount of participants that year.

The new residential sales data, according to U.S. Census Bureau (2019), shows the number of new single-family houses sold and for sale in the United States. This statistics is closely watched by investors, for the simple reason that it can be predictive of broader movements in the economy, such as the onset of a recession or the beginning of an economic recovery. The metric is also a lagging indicator of real estate demand and is driven by factors such as household income, unemployment, and interest rates (Fernando, 2019). The summary in Table 1 showed that the U.S. mean new residential sales was 659,000 with a standard deviation of 61,510, a minimum 557,000 and a maximum 738,000.

Table 1. Summary of descriptive statistics.

\begin{tabular}{|c|c|c|c|c|}
\hline Variable & Mean & SD & Minimum & Maximum \\
\hline \multicolumn{5}{|c|}{$X_{1}$ : Gross Domestic Product (GDP) } \\
\hline United States & $401,244.3$ & $522,698.2$ & $33,256.3$ & $2,997,733$ \\
\hline Northeast & $462,490.6$ & $533,471.5$ & $33,256.3$ & $1,668,866$ \\
\hline Midwest & $352,814.2$ & $256,279.3$ & $52,014.9$ & $865,310.4$ \\
\hline South & $409,741.2$ & $436,277.3$ & $73,481.3$ & $1,802,511$ \\
\hline West & $406,628.2$ & 794,057 & $39,118.5$ & $2,997,733$ \\
\hline \multicolumn{5}{|c|}{$X_{2}:$ Personal Income } \\
\hline United States & $17,813,035$ & $235,888.14$ & $17,535,505$ & $18,077,710$ \\
\hline Northeast & $1,786,038$ & $1,918,453.98$ & 135,715 & $5,367,728$ \\
\hline Midwest & $1,149,510$ & $886,331.85$ & 168,591 & $2,896,757$ \\
\hline South & $1,531,151$ & $1,573,303.59$ & 203,133 & $5,781,081$ \\
\hline West & $1,507,416$ & $2,882,075.26$ & 175,273 & $10,056,517$ \\
\hline \multicolumn{5}{|c|}{$X_{3}:$ Personal Consumption Expenditures } \\
\hline United States & 284,015 & $336,503.7$ & 24,707 & $1,858,421$ \\
\hline Northeast & 317,052 & $335,081.55$ & $31,283.8$ & $1,029,888$ \\
\hline Midwest & 220,625 & 124,216 & $36,863.1$ & 477,536 \\
\hline South & 283,318 & $294,742.34$ & 42,655 & $1,120,665$ \\
\hline West & 252,882 & 488,612 & 24,707 & $1,858,420.9$ \\
\hline \multicolumn{5}{|c|}{$X_{4}:$ Participants in the SNAP Program } \\
\hline United States & $865,475.90$ & $952,649.60$ & 33,853 & $4,340,042$ \\
\hline
\end{tabular}




\section{Continued}

$\begin{array}{ccccc}\text { Northeast } & 829,035.30 & 984,090.70 & 79,715 & 2,968,227 \\ \text { Midwest } & 726,316.90 & 626,075.60 & 54,252 & 1,914,393 \\ \text { South } & 1,101,138 & 1,036,923 & 134,625 & 3,768,472 \\ \text { West } & 710,984.50 & 1,137,372 & 33,853 & 4,340,042\end{array}$

$X_{5}$ : New Residential Sales

$\begin{array}{ccccc}\text { United States } & 659,000 & 61,510 & 557,000 & 738,000 \\ \text { Northeast } & 29,000 & 4171 & 21,000 & 34,000 \\ \text { Midwest } & 70,000 & 6725 & 63,000 & 87,000 \\ \text { South } & 389,000 & 41,072 & 310,000 & 451,000 \\ \text { West } & 171,000 & 26,569 & 121,000 & 201,000\end{array}$

$X_{6}$ : Unemployment Rate

United States
Northeast
Midwest
South
West

$X_{7}$ : Nonfarm Payroll Employment

United States
Northeast
Midwest
South
West

$\begin{array}{llll}2,978,884 & 3,291,767.4 & 289,000 & 17,344,300 \\ 3,065,378 & 3,228,601.6 & 319,500 & 9,780,500 \\ 2,897,218 & 1,951,065.1 & 441,800 & 6,197,800 \\ 3,223,829 & 3,168,848.7 & 464,100 & 12,651,000 \\ 2,667,792 & 4,531,454.8 & 289,000 & 17,344,300\end{array}$

\section{$X_{8}$ : Population of Minimum Wage Workers}

$\begin{array}{ccccc}\text { United States } & 1,614,686 & 1,762,189.84 & 121,000 & 9,798,000 \\ \text { Northeast } & 1,497,556 & 1,497,733.13 & 175,000 & 4,339,000 \\ \text { Midwest } & 1,670,545 & 1,097,492.99 & 228,000 & 3,277,000 \\ \text { South } & 1,756,353 & 1,689,359.94 & 121,000 & 6,677,000 \\ \text { West } & 1,525,538 & 2,555,292.34 & 161,000 & 9,798,000\end{array}$

\section{$X_{9}$ : Cost of Living (CPI)}

\begin{tabular}{ccccc} 
United States & 105.69 & 21.52 & 86.10 & 192.9 \\
Northeast & 120.70 & 11.50 & 101.70 & 139.10 \\
Midwest & 93.61 & 4.99 & 87.10 & 101.60 \\
South & 98.84 & 18.62 & 86.10 & 158.40 \\
West & 115.76 & 29.92 & 87.50 & 192.9 \\
\hline
\end{tabular}

Values are rounded. Source: U.S. Census Bureau (2019), Bureau of Economic Analysis (2019), Bureau of Labor Statistics (2019) and World Population Review (2020). Calculations by the author. 
Table 1 also provides descriptive statistics on the country's employment, which includes unemployment rate, nonfarm payroll employment and population of minimum wage workers. The average unemployment rate for the United States in 2018 was $3.8 \%$ with a standard deviation of $0.84 \%$, a minimum of $2.4 \%$ and a maximum of $6.6 \%$. The nonfarm payroll average is $2,978,884$, standard deviation $3,291,767.4$, a minimum of 289,000 and a maximum of $17,344,300$. The population of minimum wage workers ranged from a minimum 121,000 to a maximum $9,798,000$, with an average of 1,614,686 and a standard deviation 1,762,189.84.

The next variable deals with the cost of living with the World Population Review's cost of living index as the proxy. It is important to recognize that the World Population Review's cost of living index, in addition to being used for determining the amount of money needed to sustain a certain standard of living, is also a reliable metric for assessing how expensive it is to live in one location compared to another (World Population Review, 2020). For U.S., the average cost of living in 2018 is 105.69 with a standard deviation of 21.52 . The state cost of living index ranged from the smallest with 86.10 to the largest 192.90 .

The next thing to do is to arrange the regional descriptive statistics in Table 1 in descending order according to the magnitudes of their means. This is shown in Table 2 and, for convenience, the following acronyms are used to represent the regions in accordance with the U.S. Census Bureau classifications (U.S. Census Bureau, n.d.). Note that the states within each region were written with their official state abbreviations and are placed inside parentheses:

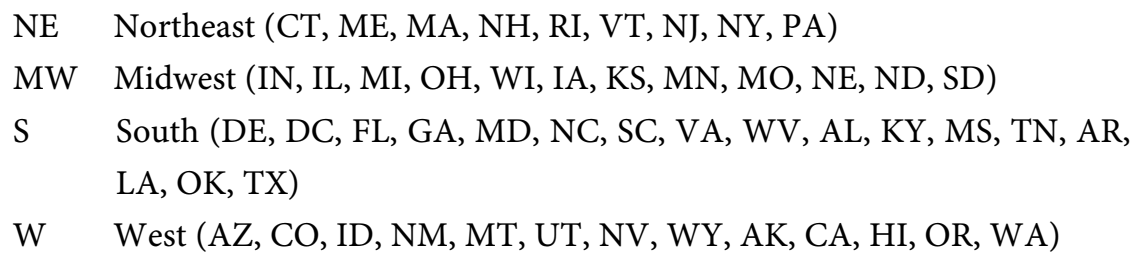

The ordering of the regions in Table 2 for the variables revealed an interesting

Table 2. Regions arranged in descending order (according to the magnitude of the means of the variables).

\begin{tabular}{ccc}
\hline Variables & Description & Regional Rank \\
\hline $\mathrm{X}_{1}$ & State GDP & NE, S, W, MW \\
$\mathrm{X}_{2}$ & Personal Income & NE, S, W, MW \\
$\mathrm{X}_{3}$ & Personal Consumption Expenditures & NE, S, W, MW \\
$\mathrm{X}_{4}$ & Participants in SNAP Program & S, NE, MW, W \\
$\mathrm{X}_{5}$ & New Residential Sales & S, W, MW, NE \\
$\mathrm{X}_{6}$ & Unemployment Rate & W, NE, S, MW \\
$\mathrm{X}_{7}$ & Nonfarm Payroll Employment & S, NE, MW, W \\
$\mathrm{X}_{8}$ & Population of Minimum Wage Workers & S, MW, W, NE \\
$\mathrm{X}_{9}$ & Cost of Living (CPI) & NE, W, S, MW \\
\hline
\end{tabular}

Note. See text for the abbreviation of regions and variables. 
Outcome, an outcome that is consistent with expectations. For instance, the top regions in the states' gross domestic product $\left(\mathrm{X}_{1}\right)$ are the same for that of personal income $\left(\mathrm{X}_{2}\right)$. Similarly, the regions ranked highest for participants in the SNAP program $\left(\mathrm{X}_{4}\right)$ are the same ranked highest for population of minimum wage workers $\left(\mathrm{X}_{8}\right)$. What is needed, however, is to use one-way analysis of variances (one-way ANOVA) to find out whether regional means for the various variables differ statistically.

Table 3 showed the results of ANOVA test of equality of the means of the 9 variables.

According to the table, with the exception of variables $\mathrm{X}_{5}$ (new residential sales) and $\mathrm{X}_{9}$ (cost of living) where the hypothesis of equality of means is rejected, the test did not reject the equality of means for the remaining seven variables with an $\alpha=0.05$ significance level. This finding is indeed very remarkable for one simple reason: it showed that, except for new residential sales and cost of living, the four U.S. regions are homogenous in terms of their individual states' GDP, personal income, personal consumption expenditure, participation in the SNAP program, unemployment rate, nonfarm payroll employment and the population of minimum wage workers.

This raises the question of where these regions differ with respect to new residential sales and cost of living. According to Bluman (2007) when the null hypothesis is rejected and a conclusion is reached that the means are not equal, the F-test does not show where the difference among the means is. That it, it does not indicate which mean differs from others. In this situation, multiple comparisons can help to determine where the significant differences in the mean lie after the ANOVA procedure have been performed. Bluman suggested two methods among many: the Scheffe test and the Tukey test. The Scheffe test is used here because it is more suitable when the samples sizes differ, which applies to

Table 3. ANOVA results.

\begin{tabular}{lcc}
\multicolumn{1}{c}{ Variable } & F & p-Value \\
\hline $\mathrm{X}_{1}$ : State GDP & 0.068 & 0.9767 \\
$\mathrm{X}_{2}$ : Personal Income & 0.1589 & 0.9233 \\
$\mathrm{X}_{3}$ : Personal Consumption Expenditure & 0.1526 & 0.9275 \\
$\mathrm{X}_{4}$ : Participants in the SNAP Program & 0.5243 & 0.6677 \\
$\mathrm{X}_{5}$ : New Residential Sales & 548.64 & 0.0000 \\
$\mathrm{X}_{6}$ : Unemployment Rate & 2.6458 & 0.0599 \\
$\mathrm{X}_{7}$ : Nonfarm Payroll Employment & 0.0702 & 0.9756 \\
$\mathrm{X}_{8}$ : Population of Minimum Wage Workers & 0.0854 & 0.9677 \\
$\mathrm{X}_{9}$ : Cost of Living & 5.0054 & 0.0044 \\
\hline
\end{tabular}

Values are rounded. Source: Calculations by the author. Raw Data Culled from U.S. Census Bureau (2019), Bureau of Economic Analysis (2019), Bureau of Labor Statistics (2019), U.S. Department of Agriculture, and World Population Review (2020) Databases. 
this study because the identified regions (northeast, midwest, south, and west) do not have equal number of states. The northeast region, for instance, is made up of 9 states, the midwest 12 states, south 16 states plus the District of Columbia, and the west 13 states. Table 4 and Table 5 showed the results of the Scheffe test.

Table 6 showed the results of the multiple comparisons using the Scheffe test.

Table 4. Scheffe Results for New Residential Sales (Scheffe Critical Value = 8.3942).

\begin{tabular}{ccc}
\hline & & Scheffe Statistic (FS) \\
\hline Northeast & Midwest & 14.5092 \\
Midwest & South & 1163.3142 \\
South & West & 571.5239 \\
Northeast & South & 1243.9734 \\
Northeast & West & 174.6913 \\
Midwest & West & 102.4355 \\
\hline
\end{tabular}

Values are rounded. Source. U.S. Census Bureau (2019) and calculations by the author.

Table 5. Scheffe Results for Cost of Living (Scheffe Critical Value $=8.4205$ ).

\begin{tabular}{ccc}
\hline & & Scheffe Statistic (FS) \\
\hline Northeast & Midwest & 9.8655 \\
Midwest & South & 0.5022 \\
South & West & 5.5165 \\
Northeast & South & 7.3532 \\
Northeast & West & 0.3390 \\
Midwest & West & 8.0038
\end{tabular}

Values are rounded. Source. World Population Review (2020) and calculations by author.

Table 6. Multiple Comparisons $(\alpha=0.05)$.

\begin{tabular}{lc}
\multicolumn{1}{c}{ Economic Variable } & Regional Comparisons \\
\hline $\mathrm{X}_{1}$ : State GDP & None \\
$\mathrm{X}_{2}$ : Personal Income & None \\
$\mathrm{X}_{3}$ : Personal Consumption Expenditure & None \\
$\mathrm{X}_{4}$ : Participants in the SNAP Program & None \\
$\mathrm{X}_{5}$ : New Residential Sales & $(\mathrm{NE}-\mathrm{MW}),(\mathrm{MW}-\mathrm{S}),(\mathrm{S}-\mathrm{W})$, \\
$\mathrm{X}_{6}:$ Unemployment Rate & $(\mathrm{NE}-\mathrm{S}),(\mathrm{NE}-\mathrm{W}),(\mathrm{MW}-\mathrm{W})$ \\
$\mathrm{X}_{7}$ : Nonfarm Payroll Employment & \\
$\mathrm{X}_{8}$ : Population of Minimum Wage Workers & \\
$\mathrm{X}_{9}$ : Cost of Living &
\end{tabular}

Values are rounded. Source: Calculations by the author. Raw Data Culled from U.S. Census Bureau (2019), Bureau of Economic Analysis (2019), Bureau of Labor Statistics (2019), U.S. Department of Agriculture, and World Population Review (2020) Databases. 
It also displays the regions that differ from others. It is important to recognize that only $\alpha<0.05$ level of significance is recorded. The results for themselves: except for cost of living and new residential sales, there are no significant differences between regional means for key economic variables. Also, the variable new residential sales $\left(\mathrm{X}_{5}\right)$ differs within all the inter-regions compared using the Scheffe test (NE-MW, MW-S, S-W, NE-S, NE-W, and MW-W). The variable cost of living $\left(\mathrm{X}_{9}\right)$, on the other hand, varied only between one inter-region (NE-MW) among all the inter-regions compared. Carried to its logical conclusion, the analysis done here would suggest that irrespective of their size, the northeast, midwest, south and western regions of the United States are indeed homogenous in terms of GDP, personal income, personal consumption expenditures, number of participants in the SNAP program, unemployment rate, nonfarm payroll employment, and the population of minimum wage workers.

\section{Conclusion}

Investigating the patterns of differences of some key economic variables among the four major U.S. regions is the objective of this research. The analysis done here was based on data obtained from the U.S. Census Bureau, the U.S. Department of Commerce, the Bureau of Economic Analysis (BEA), the Bureau of Labor Statistics, U.S. Department of Agriculture, and the World Population Review. Using a one-way ANOVA, the hypothesis of equality of means was rejected only in two of the nine selected variables. Homogenous subsets of regions were developed, and the regions that differ from each other identified by ranking the regions in descending order and through the use of Scheffe multiple comparison methods. The results for these variables were presented in Table 6. The overwhelming weight of evidence from this analysis revealed the similarity of the regions for almost all the variables examined, except for the variables, new residential sales and the cost of living. Considering this finding, it is inferred that various elements may have contributed to the similarity and homogeneity of the U.S. regions. Such elements include individual state's policies that encourage the growth of business investments and jobs, immigration, migration, education and age distribution, and so on.

The findings of the study have some important implications for businesses in general and for business founders in particular. Because there are no regional differences with respect to the variables examined (except for the variables, new residential sales and the cost of living), any kind of business can thrive in all the regions of the United States. It is worth bearing in mind that, in addition to business location, there are other factors that ensure the survival of a business such as leadership skills, efficient production, good marketing and customer service, among others. Nevertheless, the result of this study revealed that business location is not a constraint to establishing a viable company in any region of the United States.

In terms of future research, the researcher offers the following suggestions: 
first, while this paper has offered some credible evidence of the similarity of U.S. regions for important economic variables, future research needs to investigate these variables at county levels. Second, future research can go also beyond this paper's focus on the patterns of differences of some key economic variables at a regional level to investigate whether cyclical or structural changes in the U.S. economy affect the individual states similarly.

\section{Conflicts of Interest}

The author declares no conflicts of interest regarding the publication of this paper.

\section{References}

Babecky, J., Havranek, T., Mateju, M. R., Smidkova, K., \& Vasicek, B. (2013). Leading Indicators of Crisis Incidence: Evidence from Developed Countries. Journal of International Money and Finance, 35, 1-19. https://doi.org/10.1016/j.jimonfin.2013.01.001

Ball, P. (2004). Critical Mass: How One Thing Leads to Another. New York, NY: Farrar, Straus \& Giroux.

Bluman, A. G. (2007). Elementary Statistics: A Step by Step Approach. New York, NY: McGraw-Hill Higher Education.

Borio, C., \& Lowe, P. (2002). Assessing the Risk of Banking Crises. BIS Quarterly Review. https://www.bis.org/publ/qtrpdf/r qt0212e.pdf

Bureau of Economic Analysis. (2019). Personal Consumption Expenditures by State, 2019. https://www.bea.gov/news/2020/personal-consumption-expenditures-state-2019

Bureau of Labor Statistics. (2019). Graphics for Economic News Releases: Civilian Unemployment Rate. https://www.bls.gov/charts/employment-situation/civilian-unemployment-rate.htm

Cecchetti, S. G., Fender, I., \& McGuire, P. (2010). Toward a Global RiskMap. BIS Working Paper No. 309, Basel: Bank for International Settlements. https://doi.org/10.2139/ssrn.1631789

Edison, H. J. (2003). Do Indicators of Financial Crises Work? An Evaluation of an Early Warning System. International Journal of Finance and Economics, 8, 11-53. https://doi.org/10.1002/ijfe.197

Fernando, J. (2019). New Home Sales. https://www.investopedia.com/terms/n/newhomesales.asp

Forbes Media. (2018). Best States for Business-California. https://www.forbes.com/places/ca/

Garner, C. A. (1995). How Useful Are Leading Indicators of Inflation? https://core.ac.uk/download/pdf/6799565.pdf

Hubbard, R. G., \& O’Brien, A. P. (2009). Macroeconomics. Upper Saddle River, NJ: Pearson Education.

Kaminsky, G. I., \& Reinhart, C. M. (1999). The Twin Crises: The Causes of Banking and Balance-of-Payment Problems. American Economic Review, 89, 473-500.

https://doi.org/10.1257/aer.89.3.473

Kaminsky, G. L. (1999). Currency and Banking Crises: The Early Warnings of Distress. IMF Working Paper No. 99/178, Washington DC: International Monetary Fund. https://doi.org/10.5089/9781451858938.001 
https://www.imf.org/en/Publications/WP/Issues/2016/12/30/Currency-and-Banking-C rises-The-Early-Warnings-of-Distress-3372

Kaminsky, G., Lizondo, S., \& Reinhart, C. M. (1998). Leading Indicators of Currency Crises. IMF Economic Review, 45, 1-48.

Suneson, G. (2018). Wealth in America: Where Are the Richest and Poorest States Based on Household Income?

https://www.usatoday.com/story/money/economy/2018/10/08/wealth-america-househ old-income-richest-poorest-states/38051359/

U.S. Census Bureau (2019). New Residential Sales.

https://www.census.gov/construction/nrs/pdf/quarterly sales.pdf

U.S. Census Bureau. (n.d.). Census Bureau Regions and Divisions with State FIPS Codes. https://www2.census.gov/geo/pdfs/maps-data/maps/reference/us regdiv.pdf

U.S. News, \& World Report (2019). Economy Rankings: Measuring States'Economic Stability and Potential. https://www.usnews.com/news/best-states/rankings/economy

World Population Review (2020). Cost of Living Index by State.

https://worldpopulationreview.com/state-rankings/cost-of-living-index-by-state

Zhuang, J., \& Dowling, M. (2003). Lessons of the Asian Financial Crisis: What Can an Early Warning System Model Tell Us? Asian Development Review, 20, 100-113. 